\title{
Implementation of Online Learning during the Covid-19 Epidemic in Indonesia: Assessment of Higher Education Students' Use and Implementation of Online Learning Technology
}

\author{
Dian Hidayati", Wiyono Aji Saputra \\ Department of Education Management, Universitas Ahmad Dahlan, Indonesia
}

Received June 14, 2020; Revised August 10, 2020; Accepted August 25, 2020

\section{Cite This Paper in the following Citation Styles}

(a): [1] Dian Hidayati, Wiyono Aji Saputra, "Implementation of Online Learning during the Covid-19 Epidemic in Indonesia: Assessment of Higher Education Students' Use of and Implementation of Online Learning Technology," Universal Journal of Educational Research, Vol. 8, No. 10, pp. 4514-4519, 2020. DOI: 10.13189/ujer.2020.081019.

(b): Dian Hidayati, Wiyono Aji Saputra (2020). Implementation of Online Learning during the Covid-19 Epidemic in Indonesia: Assessment of Higher Education Students' Use of and Implementation of Online Learning Technology. Universal Journal of Educational Research, 8(8), 4514-4519. DOI: 10.13189/ujer.2020.081019.

Copyright $(2020$ by authors, all rights reserved. Authors agree that this article remains permanently open access under the terms of the Creative Commons Attribution License 4.0 International License.

\begin{abstract}
By the end of 2019, the Covid-19 virus was causing concern around the world. It quickly claimed Indonesian government attention - especially as the government was already anticipating a spread of online education technology around the world that was already underway. The Indonesian Ministry of Education and Culture appealed to educators for help in the creation of online programs. Researchers have tried to assess the ability of Indonesian tertiary level students to adapt to and implement online education technology. Several Indonesian universities participated in this survey. A Likert 5 item questionnaire is using to construct a "TRI" index (Index of technological preparedness). Data analysis employed descriptive statistics. Results suggest that many tertiary-level students happily agree to online lectures. Respondents were in happy agreement that online education removes inhibitions of time and distance. However, there were quite a several students who expressed anxiety at being unable to connect with necessary networks at specific times of the day. This level of insecurity in the students is different from and separate from any other feelings of dissatisfaction with the course of lectures provided.
\end{abstract}

Keywords Online Learning, Covid-19, Technology Readiness

\section{Introduction}

A severe outbreak of Covid-19 infection in Indonesia was the first notice in February 2020. According to https://www.kompas.com, by 2020/03/31, Covid-19 infection had reached 1,790 people. The Ministry of Education and Culture, Republic of Indonesia, appealed to educators to create suitable online learning programs for Elementary, Secondary, and Tertiary levels. Online courses were "to provide meaningful learning experiences, without the burden of extra-curricular demands." The ministry recognized that "there may not be sufficient occasion for socialization and there may be insufficient maintenance of infrastructure readiness, particularly electronic infrastructure to allow either student or lecturer to prepare themselves for the course.

Almost all education managers have tried to follow the ministry policy. Various platforms have tried to facilitate online learning within the capability of both student and teaching staff. This shift from the usual student/teacher face-to-face classroom situation changes both student and educator behaviours. Both parties have to adapt to new technology. The challenges are significant, especially in 
the more isolated areas, where telecommunications networks may be inadequate, and where technological gadgetry may be unavailable. Indonesia seems to particularly lack innovative learning systems in higher education that relate to Information Technology (IT), Operational Technology (OT), Internet of Things (IoT), and Big Data Analytics in the journal Widodo [1].

Today's technology can be a shortcut, but it is also flexible in its use. The utilization of technology in the field of learning in Higher Education is also a basic need, not just a matter of prestige or lifestyle. According to Lasar [2]: two obstacles affect technology: one technical, the other non-technical. Technical factors include (1) laptops and associated gadgetry; (2) Material design; (3) Financial viability. Non-technical factors include (1) Culture; (2) computer literacy. (3) familiarity with Online protocol. According to Chang and Bates [3](in the journal Mitchell \& Geva-May, [4]), Online learning requires student responses per se and also some timed short responses that have already become standard in the field of online learning. There has been little research or discussion so far concerning this authentic aspect of online learning: inhibiting factors to a small proportion of students. These are inhibitions that may exist with or without a COVID-19 pandemic.

Online learning may compare to "distance learning" an innovation that has existed since the mid-18th century. Online learning has followed from and embellished distance learning into what is now the fourth generation of Internet users. Online learning, according to Belawati [5], is any learning accomplished through the use of the internet network. The term online learning is widely synonymous with e-learning, internet learning, web-based learning, teleconference -learning, and distributed learning (Ally) [6].

There is an online learning process. It might see as an outgrowth from traditional distance learning but, of course, it can range far more widely; according to Taylor [7], distance learning breaks into five different models: correspondence, multi-media, teleconference-learning, flexible learning models and (5) the smarter flexible learning model (the intelligent Flexible Learning Model). Song et al. [8], say that most students agree that online learning can motivate and manage a student's time and that the convenience of online technology has contributed to learning successes.

The Ministry of Education indeed seems ready to gear Internet learning to creativity and innovation. Quality graduates expect to be able to bring about change and to make innovations available to the public. They want to be able to learn continuously — and that means learning from the Internet as much as current conditions allow. They do not want their learning to be dependent upon the particular comfort zone of one particular lecturer who has, throughout his career, based his instruction on only one particular set of source materials. It is too static. The ambition of the modern learner is accelerated learning.

The decision-making process of the online learner has several stages (Dacholfany, [10]): 1) Knowledge Stage: this stage takes place when a person decides that he is open to the existence of some innovation and wants to know how it functions; 2) Persuasion stage: the stage where the person decides whether he likes or dislikes the innovation; 3) Decision stage: the stage where the person moves to act in a way that either accepts or rejects the innovation; 4) Implementation phase: the stage where the person applies or uses the innovation for a specific purpose; and 5) Confirmation Stage: the stage where the person seeks to strengthen the innovation-decision he has made.

To increase learning innovation in the field of education may be necessary to prepare for changes that may, later, suppress specific values and attitudes.

Online learning is currently underway in an emergency in Indonesia only since mid-March 2020 due to the COVID-19 outbreak. This study aims to measure student satisfaction and or dissatisfaction with the online learning program currently underway because of the pandemic. All educational communities in various elements can later assess the feasibility for them of online learning. It may also indicate certain obstacles that educators, educational institutions, or universities will face.

\section{Materials and Methods}

In this study, the search for data uses descriptive qualitative (questionnaire) with respondent students from 13 provinces in Indonesia, all of whom are involved in online learning. The questionnaire poses 20 questions about their experience in online learning. They asked to assess relative optimism induced by the process and the relative innovativeness required by the online learning program. They asked to admit to any discomfort or feelings of insecurity induced by the program - the survey coded in several items to find data by comparing differences and identifying certain specific themes.

The data analysis method uses descriptive statistics. Descriptive statistics explain data numerically. The Descriptive statistics analysis has several categories: the number of variables involved, including univariate, bivariate, or multivariate (one, two, and three or more variables). This study uses a frequency distribution. Frequency distribution uses nominal, ordinal, interval, or ratio level data (Neuman, [11]). Descriptive statistics (frequency, average, and standard deviation) is using to compare each factor between TRI factors. Data analysis uses SPSS Program assistance. All questionnaire data are included in the SPSS program. The subsequent analysis is by identifying questions and analysis of Frequency Distribution. 


\section{Findings and Discussions}

Data obtained regarding the learning carried out during the Covid-19 Pandemic as shows in table 1

Table 1. Learning carried out by students

\begin{tabular}{|c|c|c|c|c|c|}
\hline \multicolumn{5}{|c|}{ College Type } \\
\hline \multirow{4}{*}{ On line } & Frequency & Per cent & $\begin{array}{c}\text { Valid } \\
\text { Percent }\end{array}$ & $\begin{array}{c}\text { Cumulative } \\
\text { Percent }\end{array}$ \\
\cline { 2 - 6 } & Not & 6 & 3.2 & 3.2 & 3.2 \\
\cline { 2 - 7 } & Yes & 182 & 96.3 & 96.3 & 99.5 \\
\cline { 2 - 7 } & Yes, no & 1 & .5 & .5 & 100.0 \\
\cline { 2 - 6 } & Total & 189 & 100.0 & 100.0 & \\
\hline
\end{tabular}

The Frequency Distribution data above is data drawn from 13 different provinces of Indonesia. It shows that 182 of the respondents were doing online learning when the pandemic COVID-19 outbreak was raging. Just six respondents were not doing online learning (3.2\%), and $0.5 \%$ is a data error.

Data on Student Satisfaction with online learning during the COVID-19 pandemic show in table 2 .

The data below shows responses to Questionnaire N, amounting to 189 individual responses. The mean below indicates the average respondent's answers to Q1: 2,9524; Q2: 2.7037; Q3: 2.6878; Q4: 2.9202 and optimism (total data on optimism): 11.2487. The median shows the same point, which is 3.0. The standard deviation of Q1 is 1.05329; Q2 is 0.99308; Q3 is 1.10747; Q4 is 1.09886, and the total amount of final optimism data is 3.61389 , $\mathrm{SD}$ is an average dispersal of the data over the sample. The percentiles of the average answer are $25 \%$ below 2.0 , $50 \%$ under 3.0, and 75\% under 4.0 . The conclusion to be drawn must be that the average student feels quite positive about online learning.

Table 2. Student Satisfaction with Online Learning

\begin{tabular}{|c|c|c|c|c|c|c|}
\hline \multicolumn{7}{|c|}{ Statistics } \\
\hline & & Q1 & Q2 & Q3 & Q4 & OPTIMISM \\
\hline \multirow{2}{*}{$\mathrm{N}$} & Valid & 189 & 189 & 189 & 188 & 189 \\
\hline & Missing & 0 & 0 & 0 & 1 & 0 \\
\hline \multicolumn{2}{|c|}{ The mean } & 2.9524 & 2.7037 & 2.6878 & 2.9202 & 11,2448 \\
\hline \multicolumn{2}{|c|}{ Median } & 3,000 & 3,000 & 3,000 & 3,000 & 11.0000 \\
\hline \multicolumn{2}{|c|}{ Mode } & 3.00 & 3.00 & 2.00 & 3.00 & $10: 00$ \\
\hline \multicolumn{2}{|c|}{ Std. Deviation } & 1.05329 & 99308 & 1.10747 & 1.09886 & 3,61389 \\
\hline \multicolumn{2}{|c|}{ Variance } & 1,109 & 986 & 1,227 & 1,208 & 13060 \\
\hline \multicolumn{2}{|c|}{ Skewness } & -.070 & .163 & .359 & .013 & .140 \\
\hline \multicolumn{2}{|c|}{ Std. Error of Skewness } & .177 & .177 & .177 & .177 & .177 \\
\hline \multicolumn{2}{|c|}{ Kurtosis } & -535 & -.507 & -648 & -764 & -.528 \\
\hline \multicolumn{2}{|c|}{ Std. Error of Kurtosis } & .352 & .352 & .352 & .353 & .352 \\
\hline \multirow{3}{*}{ Percentiles } & 25 & 2.0000 & 2.0000 & 2.0000 & 2.0000 & 9.0000 \\
\hline & 50 & 3,000 & 3,000 & 3,000 & 3,000 & 11.0000 \\
\hline & 75 & 4.0000 & 3,000 & 3,5000 & 4.0000 & 14.0000 \\
\hline
\end{tabular}


Data of Innovative Analysis in online learning during the COVID-19 pandemic is explaining in table 3.

The data below shows that it is an innovative Questionnaire N, which shows the amount of data is 189 pieces of data. The mean below indicates that the average respondent's answer is N1: 3,000; N2: 3.3386; N3: 3.1693; N4: 3,4603; N5: $2.9471 ;$ N6: 3.3333.

The median shows the same point, which is 3.0. The standard deviation of $\mathrm{N} 1$ is $1.06691 ; \mathrm{N} 2$ is $0.96295 ; \mathrm{N} 3$ is 0.98549 ; $\mathrm{N} 4$ is 1.00782 ; $\mathrm{N} 5$ is 1.04543 , N6 is 0.89324 , and the total amount of final Innovative data is $4.38161, \mathrm{SD}$ is an average disperse of data and sample. The Percentiles' average answer is $25 \%$ below $2.0,50 \%$ below 3.0 , and $75 \%$ below 4.0.

The respondents have point 3.0, which means they entirely agree with online learning. There are no limitations on distance and time. They are a means of connecting wherever they are and collecting several kinds of assignments without having to go to the classroom. Students can work on and receive assignments at home or outside the home. However, the students still use the same learning process schedule as before.

Data of student dissatisfaction with online learning during the COVID-19 pandemic shows in table 4 .

Table 3. Innovative Analysis

\begin{tabular}{|c|c|c|c|c|c|c|c|c|}
\hline \multicolumn{9}{|c|}{ Statistics } \\
\hline \multirow{3}{*}{$\mathrm{N}$} & & N1 & N2 & N3 & N4 & N5 & N6 & Innovative \\
\hline & Valid & 189 & 189 & 189 & 189 & 189 & 189 & 189 \\
\hline & Missing & 0 & 0 & 0 & 0 & 0 & 0 & 0 \\
\hline \multicolumn{2}{|c|}{ The mean } & 3,000 & 3.3386 & 3.1693 & 3,4603 & 2.9471 & 3.3333 & 19,247 \\
\hline \multicolumn{2}{|c|}{ Median } & 3,000 & 3,000 & 3,000 & 4.0000 & 3,000 & 3,000 & 19.0000 \\
\hline \multicolumn{2}{|c|}{ Mode } & 3.00 & 4.00 & 3.00 & 4.00 & 2.00 & 4.00 & 7:00 p.m. \\
\hline \multicolumn{2}{|c|}{ Std. Deviation } & 1.06691 & .96295 & .98549 & 1.00782 & 1.04543 & .89324 & 4.38161 \\
\hline \multicolumn{2}{|c|}{ Variance } & 1,138 & .927 & .971 & 1,016 & 1,093 & .798 & 19,198 \\
\hline \multicolumn{2}{|c|}{ Skewness } & .106 & -.255 & .024 & -.269 & 276 & -.392 & .100 \\
\hline \multicolumn{2}{|c|}{ Std. Err of Skewness } & .177 & .177 & .177 & .177 & .177 & .177 & .177 \\
\hline \multicolumn{2}{|c|}{ Kurtosis } & -717 & -.602 & -687 & -611 & -736 & -.098 & -.409 \\
\hline \multicolumn{2}{|c|}{ Std. Error of Kurtosis } & .352 & .352 & .352 & .352 & .352 & .352 & .352 \\
\hline \multirow{3}{*}{ Percentiles } & 25 & 2.0000 & 3,000 & 2.0000 & 3,000 & 2.0000 & 3,000 & 16.0000 \\
\hline & 50 & 3,000 & 3,000 & 3,000 & 4.0000 & 3,000 & 3,000 & 19.0000 \\
\hline & 75 & 4.0000 & 4.0000 & 4.0000 & 4.0000 & 4.0000 & 4.0000 & 22.0000 \\
\hline
\end{tabular}

Table 4. Analysis of Student Dissatisfaction

\begin{tabular}{|c|c|c|c|c|c|c|}
\hline \multicolumn{7}{|c|}{ Statistics } \\
\hline & & DIS1 & DIS2 & DIS3 & DIS4 & Discomfort \\
\hline \multirow{2}{*}{$\mathrm{N}$} & Valid & 189 & 189 & 189 & 189 & 189 \\
\hline & Missing & 0 & 0 & 0 & 0 & 0 \\
\hline \multicolumn{2}{|c|}{ The mean } & 2.4709 & 2.8042 & 2.8042 & 3.3228 & 11.4021 \\
\hline \multicolumn{2}{|c|}{ Median } & 2.0000 & 3,000 & 3,000 & 3,000 & 12.0000 \\
\hline \multicolumn{2}{|c|}{ Mode } & 2.00 & 3.00 & 3.00 & 4.00 & 12.00 \\
\hline \multicolumn{2}{|c|}{ Std. Deviation } & 1.06464 & .92183 & 1.07128 & 1.12352 & 2,52587 \\
\hline \multicolumn{2}{|c|}{ Variance } & 1,133 & .850 & 1,148 & 1,262 & 6,380 \\
\hline \multicolumn{2}{|c|}{ Skewness } & .464 & .070 & .136 & -.164 & -041 \\
\hline \multicolumn{2}{|c|}{ Std. Error of Skewness } & .177 & .177 & .177 & .177 & .177 \\
\hline \multicolumn{2}{|c|}{ Kurtosis } & -.459 & -356 & -624 & $-1,000$ & -.005 \\
\hline \multicolumn{2}{|c|}{ Std. Error of Kurtosis } & .352 & .352 & .352 & .352 & .352 \\
\hline \multirow{3}{*}{ Percentiles } & 25 & 2.0000 & 2.0000 & 2.0000 & 2.0000 & 10,0000 \\
\hline & 50 & 2.0000 & 3,000 & 3,000 & 3,000 & 12.0000 \\
\hline & 75 & 3,000 & 3,000 & 4.0000 & 4.0000 & 13.0000 \\
\hline
\end{tabular}


The data above shows that Questionnaire N, which shows the amount of data, is 189 pieces of data. The mean above shows the respondent's data answer DIS1: 2.4709; DIS2: 2.8042; DIS3: 2.8042; DIS4: 3.3228 and discomfort (total data disruption or discomfort online learning): 11.4021. The median shows the same point, namely dis1: 2.0, dis2: 3.0, dis3: 3.0, dis4: 3.0. The standard deviation of DIS1 is 1.0646 ; DIS2 is 0.92183 DIS3 is 1.07128; Q4 is 1.12352, and the total amount of final discomfort data is $2.52587, \mathrm{SD}$ is an average disperse of data and samples. Percentiles: The average answer is $25 \%$ below $2.0,50 \%$ below 2.0 , and $75 \%$ below 3.0

The data suggests that the students experienced much disruption when studying online due to Indonesia's inadequate network factors and geographic infrastructure factors. Student satisfaction with online learning partly depends on adequate surrounding infrastructure: adequate electrical current, and it can depend too on suitable weather conditions. However, the network is good; sometimes, the weather also determines the web in the area-average data point 2.0, which means that the students discomfort using the online learning process.

Data on feelings of insecurity induced by online learning during the COVID-19 pandemic are shown in table 5 .

The data below shows that Questionnaire N, which shows the amount of data, is 189 pieces of data. The mean below shows the respondent data answer INS1: 2.6667; INS2: 2,3651; INS3: 3.4550; INS4: 2.5661; INS5: 2.3862 and insecurity (the amount of insecurity data online learning): 13.4392. The median shows the same point, namely dis1: 3.0, dis2: 2.0, dis3: 4.0, dis4: 2.0. The standard deviation of INS1 is 0.99467 ; INS2 is 0.95039 INS3 is 0.99163 ; INS4 is 0.85808 ; INS5 is 1.14577 , and the total number of Insecurity final data is 3.10503 , SD is an average disperse of data and samples. The Percentiles: The average answer is $25 \%$ under $3.0,50 \%$ under 4.0 , and $75 \%$ under 4.0

The data below shows that the learning programs were not smoothly running and required better development. At a perceived level of 2:0, many of the respondents felt insecure while engaging in the online learning process.

This level of discomfort suggests that many of the students, even most of the students, faced problems with inferior communications networks, wrong geographical location, and inadequate facilities generally. However, for those students living in town centres, adequate networks should not be a problem. During the pandemic, many of the students, even those near town centres, preferred to work from home. Finally, at the level of insecurity or insecurity, most respondents choose point 2.0 together with discomfort.

The students need some improvement to improve the learning system if we want to apply online learning. The communication network facilities and infrastructures provide insight into technological advancements for elderly lecturers and create the latest innovations in Indonesia for online or online learning.

Table 5. Analysis of insecurity statistics

\begin{tabular}{|c|c|c|c|c|c|c|c|}
\hline & & INS1 & INS2 & INS3 & INS4 & INS5 & Insecurity \\
\hline \multirow{2}{*}{$\mathrm{N}$} & Valid & 189 & 189 & 189 & 189 & 189 & 189 \\
\hline & Missing & 0 & 0 & 0 & 0 & 0 & 0 \\
\hline \multicolumn{2}{|c|}{ The mean } & 2.6667 & 2,3651 & 3.4550 & 2.5661 & 2.3862 & 13,4392 \\
\hline \multicolumn{2}{|c|}{ Median } & 3,000 & 2.0000 & 4.0000 & 3,000 & 2.0000 & 14.0000 \\
\hline \multicolumn{2}{|c|}{ Mode } & 3.00 & 2.00 & 4.00 & 2.00 & 2.00 & 2:00 p.m. \\
\hline \multicolumn{2}{|c|}{ Std. Deviation } & 99467 & .95039 & 99163 & 85808 & 1.14577 & 3.10503 \\
\hline \multicolumn{2}{|c|}{ Variance } & .899 & .903 & .983 & .736 & 1,313 & 9,641 \\
\hline \multicolumn{2}{|c|}{ Skewness } & .219 & .563 & -.255 & .150 & .422 & .069 \\
\hline \multicolumn{2}{|c|}{ Std. Error of Skewness } & .177 & .177 & .177 & .177 & .177 & .177 \\
\hline \multicolumn{2}{|c|}{ Kurtosis } & -344 & -001 & -.537 & -440 & -.909 & -.131 \\
\hline \multicolumn{2}{|c|}{ Std. Error of Kurtosis } & .352 & .352 & .352 & .352 & .352 & .352 \\
\hline \multirow{3}{*}{ Percentiles } & 25 & 2.0000 & 2.0000 & 3,000 & 2.0000 & 1.0000 & 11.0000 \\
\hline & 50 & 3,000 & 2.0000 & 4.0000 & 3,000 & 2.0000 & 14.0000 \\
\hline & 75 & 3,000 & 3,000 & 4.0000 & 3,000 & 3,000 & 15.0000 \\
\hline
\end{tabular}




\section{Conclusions}

The four points on the questionnaire indicate that online learning conducted in Indonesia has many obstacles. One of them is the personal readiness constraints of students who are not ready to carry out online learning that is too impromptu without any socialization. The next obstacle is the follow-up from the Indonesian Ministry of Education and Culture in responding to disaster preparedness, whatever the type of disaster, it is necessary to have support through the Ministry of Communication and Information or the Ministry of Communication and Information to increase or improve the quality of the Internet network throughout Indonesia. Not only those in the middle of the city who can enjoy the system but in remote areas and at the village, the government must pay attention - many students and universities in Indonesia located in remote villages. With the Covid-19 disaster, all universities must stop activities. Finally, at the Lecturer level, students feel dissatisfied with online learning provided by the lecturer. Based on the data, the level of satisfaction reduced in education, and the students do not have a learning process but should do the tasks. The responses of lecturers in online learning are slow.

\section{Acknowledgements}

Thanks to Universitas Ahmad Dahlan, Universitas Pendidikan Indonesia, Wiralodra of University, Bengkulu of University, IAIN Syaikh Abdurrahman Siddik Bangka Belitung, and other universities for providing opportunities to retrieve data from students.

\section{REFERENCES}

[1] Widodo, H. (2016). Potret Pendidikan Di Indonesia Dan Kesiapannya Dalam Menghadapi Masyarakat Ekonomi Asia (Mea). Cendekia: Journal of Education and Society, 13(2), 293. https://doi.org/10.21154/cendekia.v13i2.250
[2] Indriyani, E. (2005). PENGELOLAAN SISTEM INFORMASI AKADEMIK PERGURUAN TINGGI BERBASIS TEKNOLOGI INFORMASI DAN KOMUNIKASI (TIK). Universitas Pendidikan Indonesia, 24(10), 82-83.

[3] Bates, A.W. (2000). Managing technological change: Strategies for college and university leaders. San Fransisco: Jossey-Bass Publishers.

[4] Mitchell, B., \& Geva-May, I. (2009). Attitudes were affecting online learning implementation in higher education. The Journal of Distance Education/Revue de 1' ..., 23(1), 7188.

http://www.jofde.ca/index.php/jde/article/view/43\%5Cnhttp ://www.jofde.ca/index.php/jde/article/viewArticle/43

[5] Belawati, T. (2019). Pembelajaran Online. In Kementerian Riset, Teknologi, dan Pendidikan Tinggi (Issue December 2019, p. 7). Universitas Terbuka Kementerian Riset, Teknologi, dan Pendidikan Tinggi.

[6] Ally, M. (2008). Foundation for educational theory for online learning. In T. Anderson (Ed.). The Theory and Practice of Online Learning, Second Edition (pp. 1-120). Edmonton, Canada: AU Press.

[7] Taylor, J. (2000). New millennium distance education. Dalam V. Reddy \& S. Manjulika (Eds). The world of open and distance learning. New Delhi: Viva.

[8] Song, L., Singleton, E. S., Hill, J. R., \& Koh, M. H. (2004). Improving online learning: Student perceptions of useful and challenging characteristics. Internet and Higher Education, 7(1), 59-70. https://doi.org/10.1016/j.iheduc.2003.11.003

[9] Fuady, M. J. (2016). PENGEMBANGAN APLIKASI EVALUASI PEMBELAJARAN ONLINE UNTUK PENDIDIKAN JARAK JAUH Muhammad Jauharul Fuady. Tekno, 26(September), 148-154.

[10] Dacholfany, M. I. (2016). Peranan Pengambilan Keputusan dalam Rangka Menciptakan Inovasi di Bidang Pendidikan. Dewantara, 1(1), 16-28.

[11] Neuman, W. L. (2014). Social Research Methods; Qualitative and Quantitative Approaches Seventh Edition. In Pearson. http://arxiv.org/abs/1210.1833\%0Ahttp://www.jstor.org/sta ble/3211488? origin=crossref\%0Ahttp://www.ncbi.nlm.nih. gov/pubmed/12655928 